\title{
Maternal Obesity and Congenital Anomalies: Its Implications and Future Trends
}

\author{
${ }^{1}$ Gayatri Madhab, ${ }^{2}$ Arindam Bharadwaz
}

\begin{abstract}
Objectives: To find the current body of evidence for maternal obesity's association with and its burden on congenital malformations and to estimate its financial and mortality implications as well as future trend.
\end{abstract}

Materials and methods: Thorough search and review of current literature with deductive interpretations.

Results and evidence: Obesity is associated with certain types of congenital anomalies like neural tube defects (NTD), congenital heart defects (CHDs), orofacial defects, etc. The burden in absolute numbers for major CHD and NTD attributable to obesity can be estimated to be 0.42 to 1.05 and 0.588 to 1.12 per 10,000 births respectively.

Remarks and conclusion: Contribution of maternal obesity on perinatal mortality could be anywhere from 6 to 20 per 1,00,000 births. However, its economic implications could be substantial. Current trend indicates that contribution of obesity to certain congenital anomalies may increase in future.

Keywords: Congenital anomalies, Congenital anomaly trends, Implication of congenital malformations, Maternal obesity.

How to cite this article: Madhab G, Bharadwaz A. Maternal Obesity and Congenital Anomalies: Its Implications and Future Trends. J South Asian Feder Obst Gynae 2015;7(3):134-142.

Source of support: Nil

Conflict of interest: None

Date of received: 18 July 2015

Date of acceptance: 10 September 2015

Date of publication: December 2015

\section{INTRODUCTION}

Overweight and obesity have been growing rapidly in the world in the past few decades accounting for about 1.4 billion overweight people of which 200 million men

\footnotetext{
${ }^{1}$ Resident, ${ }^{2}$ Consultant

${ }^{1}$ Department of Obstetrics and Gynecology, Sygehus Vendsyssel, Denmark

${ }^{2}$ Department of Radiology, Aarhus University Hospital Denmark

Corresponding Author: Gayatri Madhab, Resident Department of Obstetrics and Gynecology, Sygehus Vendsyssel, Denmark, Phone: +45 9764 0000, e-mail: gayatrimajoni@yahoo.co.in
}

and 300 million women were obese. ${ }^{1}$ In the UK and USA, about 33 to $40 \%$ of all pregnant women are overweight or obese; ${ }^{2-4}$ whereas in India and China, the burden is anywhere between 8 and $26 \% .5,6$ Besides the overall long-term risk for diabetes, cardiovascular disease and cancer, overweight and obesity are also associated with many pregnancy and birth complications.

\section{OBJECTIVES}

Various studies have shown association of obesity with some types of congenital anomalies. But, the exact burden of obesity on congenital anomalies, its financial and mortality implications are not well documented in the literature. Aim of our present work is to review current literature to find the body of evidence associating maternal obesity with congenital malformations and overall burden of obesity on congenital malformations, their implications and future trends.

\section{LITERATURE SEARCH AND SELECTION}

The primary source of materials has been through Aarhus University Hospital (www.ascag.as.aaa.dk), Pubmed (http://www.ncbi.nlm.nih.gov/pubmed/), and www.google.com. References from the original articles were freely used. Key search words were 'obesity and congenital anomalies', 'congenital anomalies associated with obesity', 'burden/contribution of obesity on congenital anomalies', 'implications of congenital anomalies', 'future trends in congenital anomalies', etc. Out of 50 odd papers 24 current and contemporary papers published between 1999 and 2012 were selected for review and divided according to study design. 6 prospective/cohort studies, 13 retrospective/case control studies, 1 cross-sectional study, 2 review articles and 2 meta-analyses are included in the comparative list.

\section{Obesity-Definition}

Overweight and obesity are defined as abnormal/ excessive accumulation of fat that poses a health-risk. They are classified according to body mass index (BMI) defined as weight in kilograms divided by height in meter, ${ }^{2}$ i.e. BMI $=\mathrm{kg} / \mathrm{m}^{2}{ }^{1,7}$ The standard World Health organization (WHO) classification of BMI is widely 
Table 1: Classification of adult underweight, normal weight, overweight and obesity according to BMI aligned after WHO classification

\begin{tabular}{ll}
\hline Classification & $B M I\left(\mathrm{~kg} / \mathrm{m}^{2}\right)$ \\
\hline Underweight & $<18.50$ \\
Normal weight & $18.50-24.99$ \\
Overweight & $25.00-29.99$ \\
Obese & $>30.00$ \\
Class I & $30.00-34.99$ \\
Class II & $35.00-39.99$ \\
Class III & $>40.00$ \\
\hline
\end{tabular}

followed $^{8}$ where BMI $>25$ and $>30$ are defined as overweight and obesity respectively (Table 1 ).

Most studies in our review categorized or matched prepregnancy BMI according to the WHO classification. Moor et al, however, categorized obesity as BMI > 28; Watkins and Botto clubbed overweight and obesity together with BMI $>26$, Ray et al in quartiles and deciles, Biggio as per weight in $\mathrm{lb}$ and Feldman according to $\mathrm{lb}$ or $\mathrm{kg}^{9-13}$

\section{Obesity and Congenital Anomalies- Current Evidence}

World Health Organization defines congenital anomalies as structural or functional anomalies, including metabolic disorders, present at birth. ${ }^{14}$ Twenty-two studies in our review reported association of congenital defects with obesity. Eleven studies reported association with neural tube defects (NTD), nine studies with congenital heart defects (CHD), five studies with orofacial, four studies with musculoskeletal, one study with renal and obstructive and one study with eye anomalies. Six studies reported multisystem anomalies of which NTD, $\mathrm{CHD}$ and orofacial-anomalies were predominant. Most studies reported either an overall increase in congenital defects or specific congenital anomalies associated with obesity (Table 2).

Odds ratio (OR) for NTDs ranged from lowest 1.7 (95\% CI 1.34-2.15) for all NTDs to highest 3.5 (95\% CI 1.2 - 10.3) for spina bifida (11 studies), for CHD from lowest 1.15 (95\% CI 1.07 - 1.23) to highest 2.0 (95\% CI 1.2 - 3.4) (9 studies) and for orofacial clefts from lowest $1.2(95 \%$ CI $1.09-1.31)$ for septal defects to highest 3.71 (95\% CI 1.05 - 13.10) for cleft lip (5 studies). Several studies have also mentioned that compounding factors along with obesity increase the risk of congenital anomalies. Moore et al have mentioned a three-fold increased risk of congenital anomalies when diabetes and obesity are combined with PR $=3.1(95 \% \mathrm{CI}$ $1.2-7.6)$ but no significant association with either obesity (BMI > 28) or diabetes alone. ${ }^{9}$ Multiplicative interaction with diabetes has also been noted by Anderson et al. ${ }^{15}$ Hyperinsulinemia appears to be an independent risk factor for NTD and may be the driving force of observed risk of NTD in obese. ${ }^{16}$ Honein et $a{ }^{17}$ found increased risk of renal and obstructive anomalies with joint exposures to high BMI and subfertility but not for either exposure alone (Table 3).

Feldman et al however did not find any statistically significant difference between obese and nonobese using different cut-off points for obesity. ${ }^{13}$ Biggio et al using obesity criteria of either BMI $>29 \mathrm{~kg} / \mathrm{m}^{2}$ or $200 \mathrm{lb}$ cut-off found no significant independent association between obesity and major congenital anomalies. ${ }^{12}$ Shaw et al found no association with major congenital anomalies except for an overall increase in NTD. ${ }^{18}$

\section{LIMITATIONS}

There are many inherent limitations in the reviewed studies. Obesity has been defined differently by different studies, although 17 studies matched WHO criteria of obesity. Three studies included termination of pregnancy for fetal anomalies (TOPFA), late miscarriage, still birth and live births in their studies whereas three other studies included all but late miscarriage. Studies relied on selfreported height and weight which can be fraught with under-reporting and recall bias. Association of obesity with individual anomaly-subtypes lacks adequate power.

\section{Burden of Obesity on Congenital Anomalies}

Congenital anomalies affect approximately 1 in 33 births corresponding to about 3.2 million birth defect related disabilities every year. ${ }^{14}$ Prevalence of major congenital anomalies in Europe was 23.9 per 1,000 births from 2003 to 2007 and 20.9 per 1,000 births from 2007 to 2011 . The most common anomaly has been nonchromosomal CHD at 6.5/1000 for 2003 to 2007 and 5.8/1000 for 2007 to 2011. NTDs stand at about $0.77 / 1000$ for 2007 to $2011 .{ }^{19,20}$ In the UK major CHD rate is from 14.1 to 35 per 10,000 births and open NTD (spina bifida) is from 6 to 11.5 per 10,000 births. ${ }^{21-23}$

An estimated 3.0\% (0.5 - 5.4) of CHDs and 9.8\% (5.614.1) of NTDs in England are attributable to maternal obesity (BMI $>30 \mathrm{~kg} / \mathrm{m}^{2}$ ) with absolute risks for the same being $75(95 \% \mathrm{CI}=66-84)$ and $19(95 \% \mathrm{CI}=1.6-$ 2.2) per 10,000 births respectively. ${ }^{24}$ Absolute number of nonchromosomal CHD and NTD are 489 and 299 respectively (BINOCAR 2010). ${ }^{22}$ Extrapolation to previously mentioned UK data shows that major CHD and NTD attributable to obesity can be approximated to 0.42 to 1.05 and 0.588 to 1.12 per 10,000 births or roughly 15 and 29 respectively per 642397 births (averaged) per year in England and Wales from 1998 to $2008 .{ }^{25}$ In the USA, where prevalence of NTD and CHD is approximately 


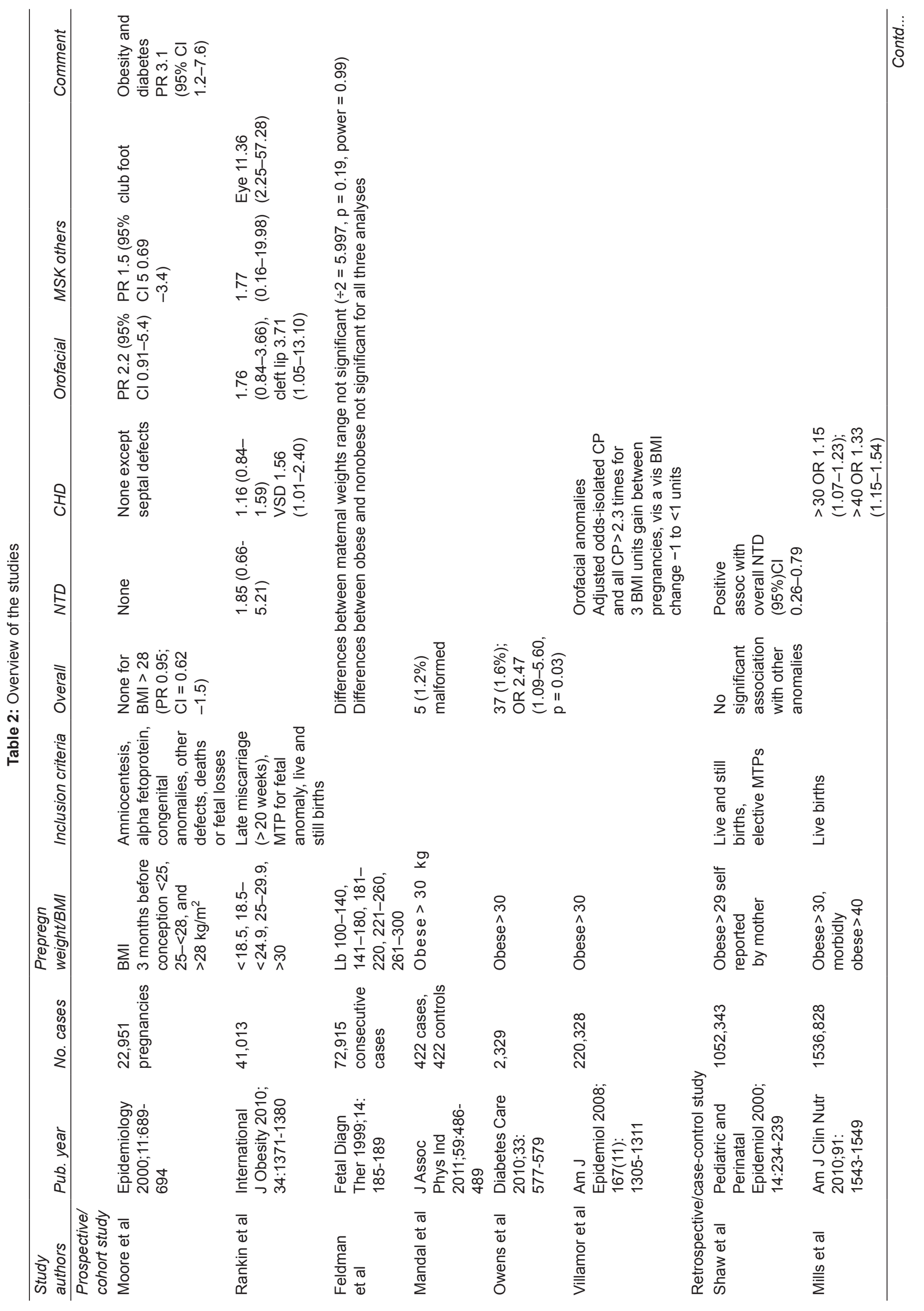




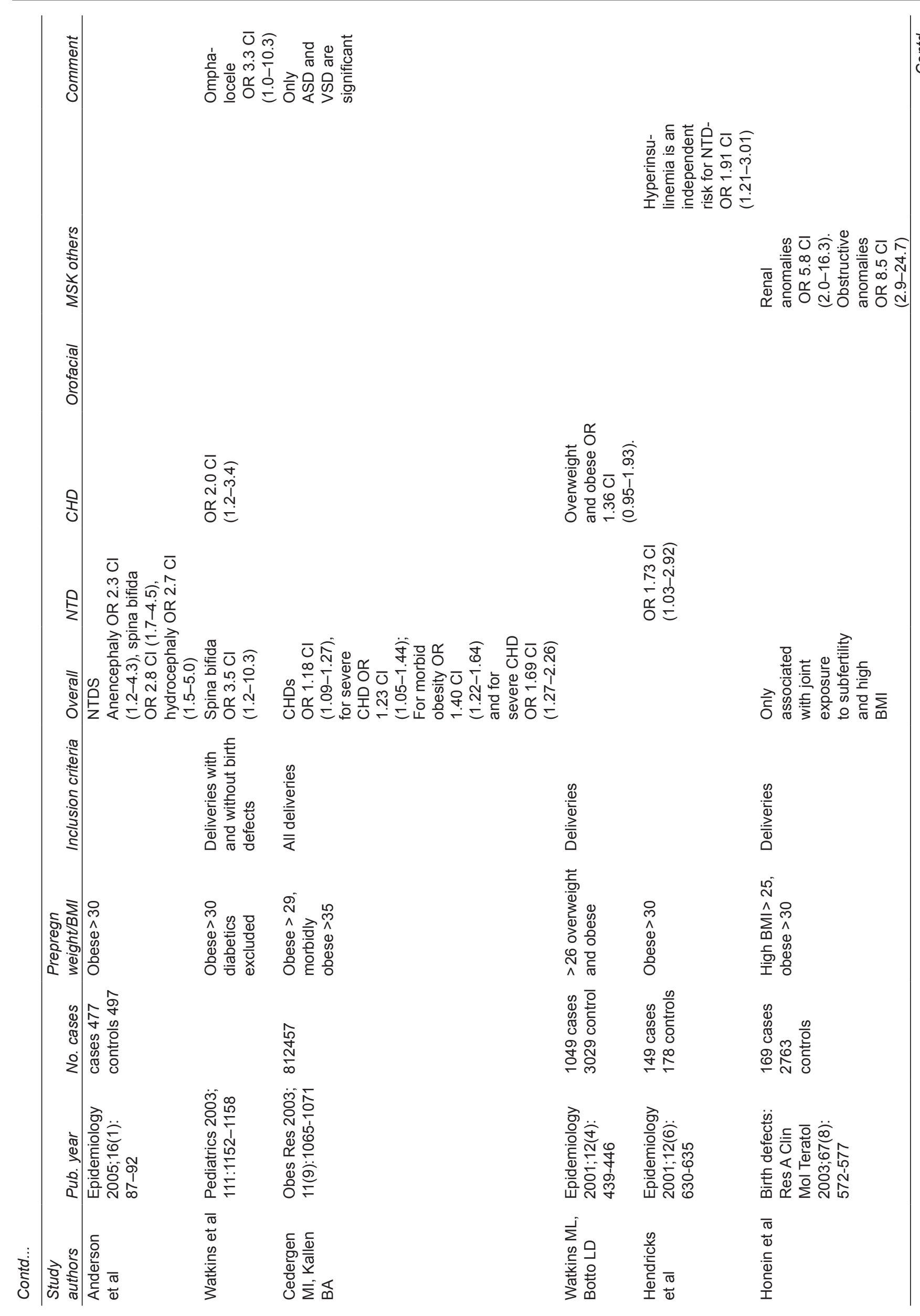



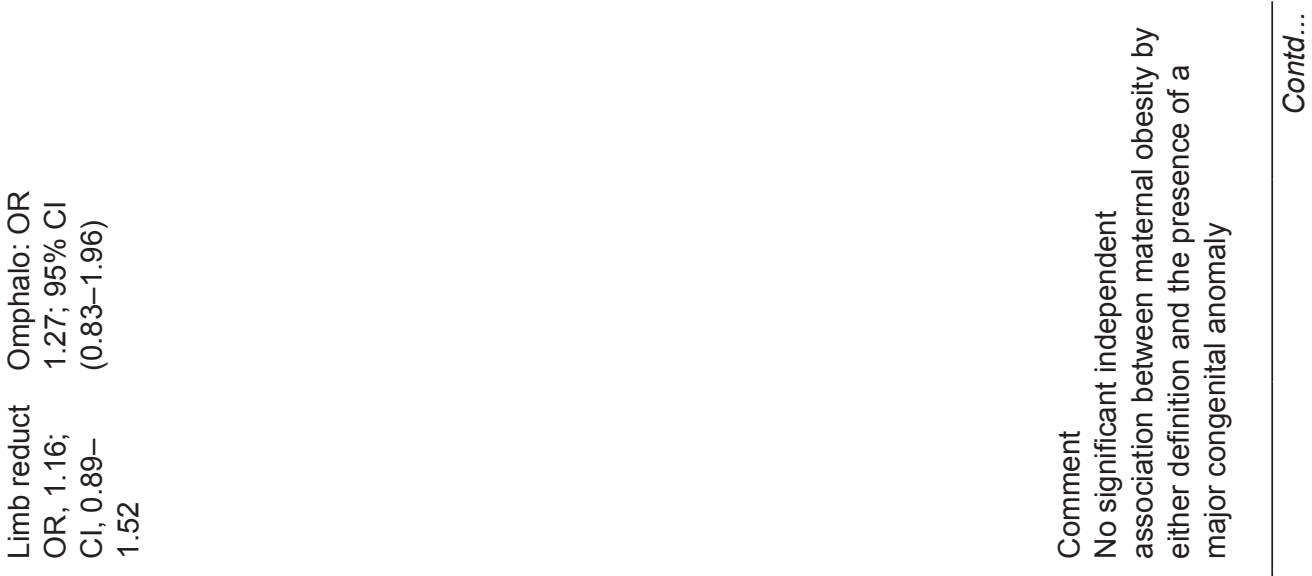

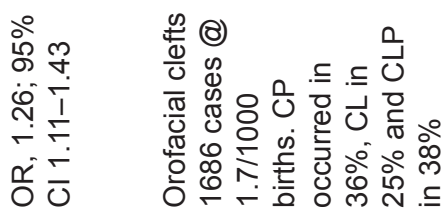

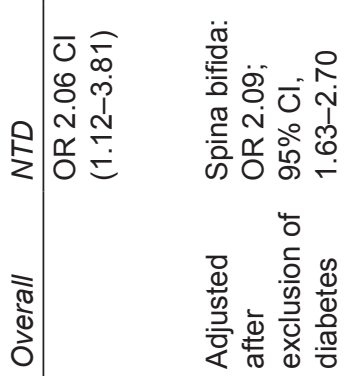

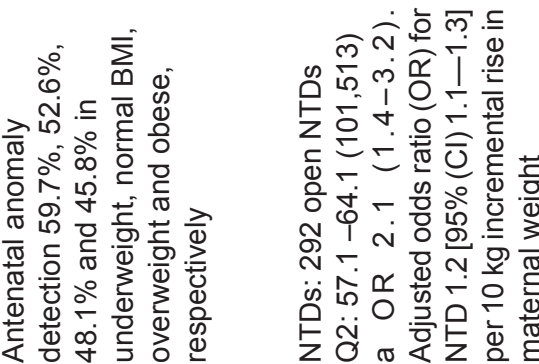

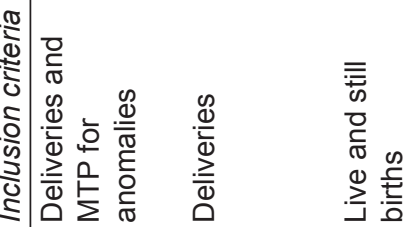

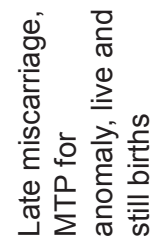

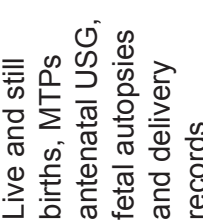
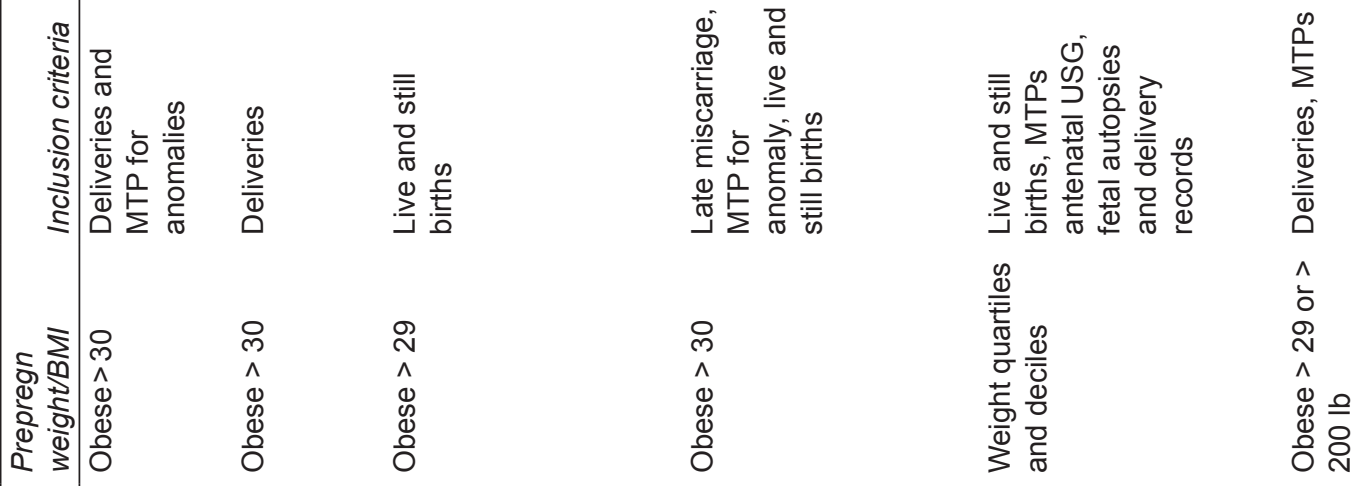

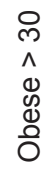
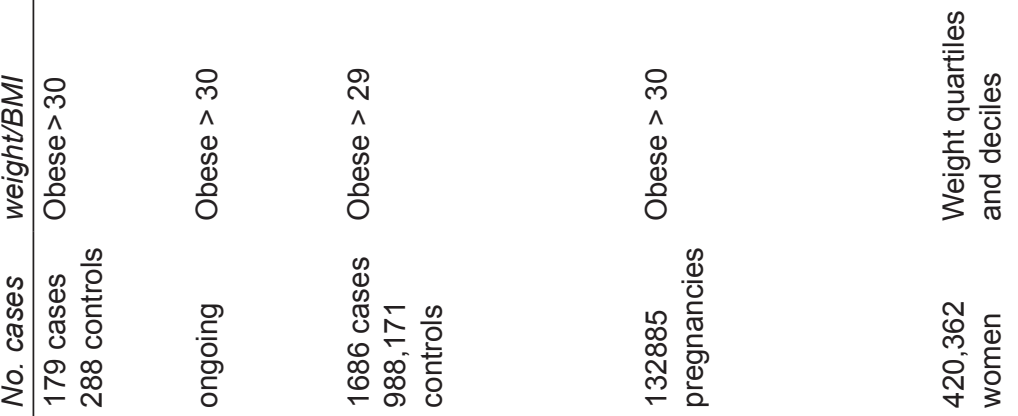

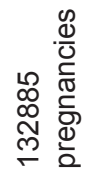

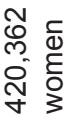

ণั

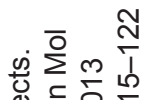

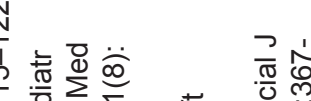

๑

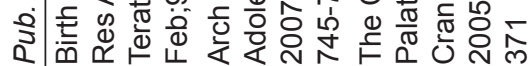

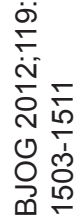
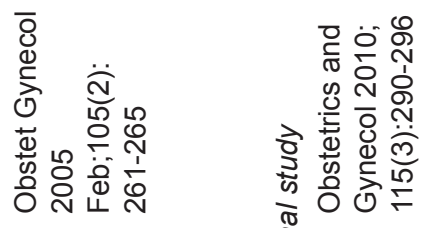

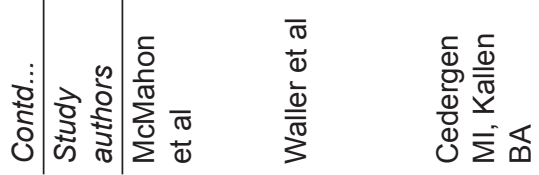

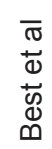

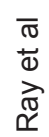




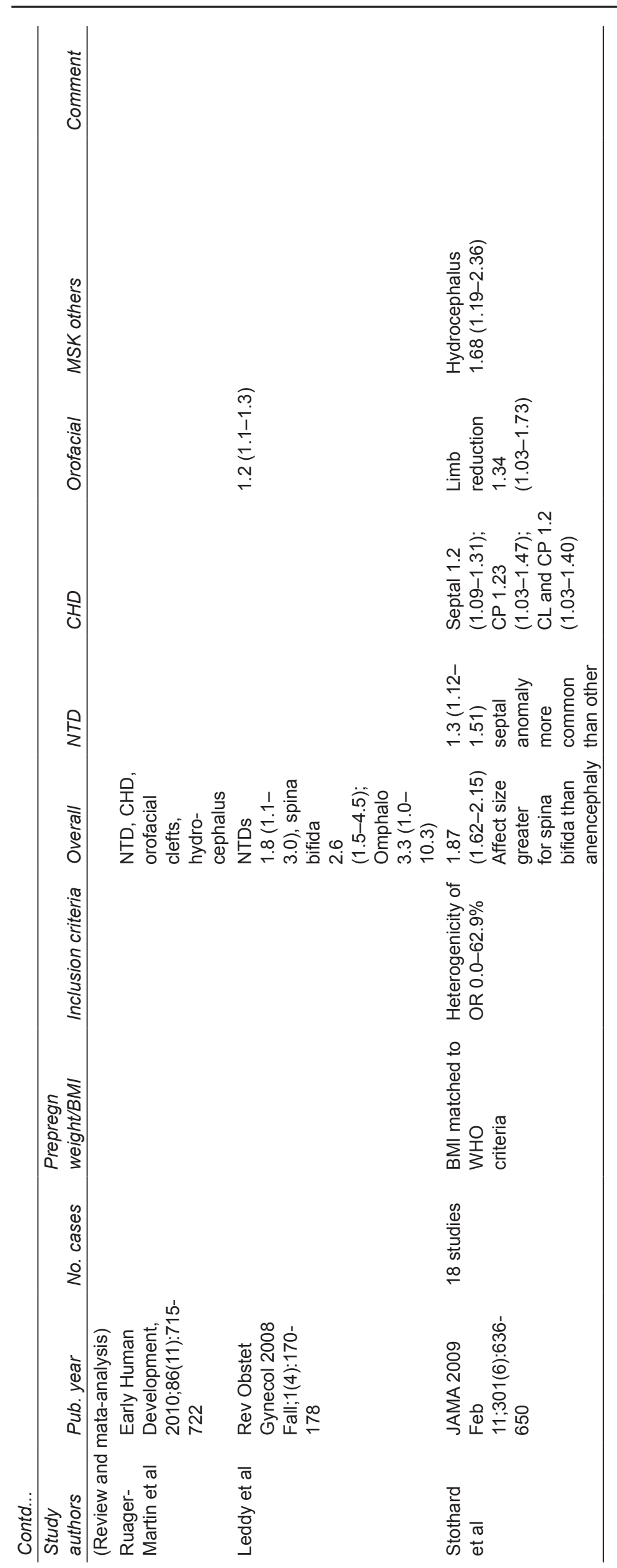


Table 3: Risks of specific anomalies

\begin{tabular}{|c|c|c|c|c|c|}
\hline Authors & \multicolumn{4}{|l|}{ Anomalies } & Comment \\
\hline Rankin et al & & & 1.85 & $0.66-5.21$ & \\
\hline Shaw et al & \multicolumn{2}{|c|}{$\begin{array}{l}\text { Positive association with overall } \\
\text { NTD }\end{array}$} & & $0.26-0.79$ & $\begin{array}{l}\text { Multivitamin and diabetes did not } \\
\text { significantly alter findings }\end{array}$ \\
\hline Anderson et al & \multicolumn{2}{|l|}{$\begin{array}{l}\text { Anencephaly } \\
\text { Spina bifida } \\
\text { Hydrocephaly }\end{array}$} & $\begin{array}{l}2.3 \\
2.8 \\
2.7\end{array}$ & $\begin{array}{l}1.2-4.3 \\
1.7-4.5 \\
1.5-5.0\end{array}$ & $\begin{array}{l}\text { OR is higher with simultaneous diabetes } \\
\text { showing multiplicative interaction }\end{array}$ \\
\hline Watkins et al & \multirow{2}{*}{\multicolumn{2}{|c|}{ Spina bifida }} & 3.5 & $1.2-10.3$ & \\
\hline Hendricks et al & & & 1.73 & $1.03-2.92$ & $\begin{array}{l}\text { Hyperinsulinemia independent risk for NTD } \\
-\mathrm{OR} 1.91 \mathrm{Cl}(1.21-3.01) \text {-may be driving } \\
\text { force of risk of NTD in obese }\end{array}$ \\
\hline McMahon et al & & & 2.06 & $1.12-3.81$ & \\
\hline Waller et al & \multirow{2}{*}{\multicolumn{2}{|c|}{$\begin{array}{l}\text { Spina bifida } \\
\text { adjusted odds ratio (aOR)-Q2: } \\
57.1-64.1(101,513) \\
\text { aOR for NTD per } 10 \mathrm{~kg} \text { rise in } \\
\text { maternal weight }\end{array}$}} & 2.09 & $1.63-2.70$ & \\
\hline Ray et al & & & $\begin{array}{l}2.1 \\
1.2\end{array}$ & $\begin{array}{l}1.4-3.2 \\
1.1-1.3\end{array}$ & $\begin{array}{l}\text { For the highest compared with lowest } \\
\text { weight deciles (adjusted OR 3.3, 95\% Cl } \\
1.7-6.2 \text { ) }\end{array}$ \\
\hline Leddy et al & \multicolumn{2}{|l|}{$\begin{array}{l}\text { Overall } \\
\text { Spina bifida }\end{array}$} & $\begin{array}{l}1.8 \\
2.6\end{array}$ & $\begin{array}{l}1.1-3.0 \\
1.5-4.5\end{array}$ & \\
\hline Rasmussen et al & \multicolumn{2}{|l|}{$\begin{array}{l}\text { Overweight } \\
\text { Obese } \\
\text { Severely obese }\end{array}$} & $\begin{array}{l}1.22 \\
1.7 \\
3.11\end{array}$ & $\begin{array}{l}0.99-1.49 \\
1.34-2.15 \\
1.75-5.46\end{array}$ & \\
\hline \multirow[t]{2}{*}{ Stothard et al } & & & 1.87 & $1.62-2.15$ & $\begin{array}{l}\text { Affect size greater for spina bifida than } \\
\text { anencephaly }\end{array}$ \\
\hline & \multicolumn{2}{|l|}{$\mathrm{CHD}$} & OR & $95 \% \mathrm{Cl}$ & Comment \\
\hline Moore et al & \multicolumn{2}{|c|}{ None except septal defects } & NA & NA & \\
\hline Rankin et al & \multicolumn{2}{|c|}{$\begin{array}{l}\text { CHD most common anomaly } \\
\text { VSD }\end{array}$} & $\begin{array}{l}1.16 \\
1.56\end{array}$ & $\begin{array}{l}0.84-1.59 \\
1.01-2.40\end{array}$ & \\
\hline Mills et al & \multicolumn{2}{|l|}{$\begin{array}{l}\mathrm{BMI}>30 \\
\mathrm{BMI}>40\end{array}$} & $\begin{array}{l}1.15 \\
1.33\end{array}$ & $\begin{array}{l}1.07-1.23 \\
1.15-1.54\end{array}$ & $\begin{array}{l}\text { Includes all CHD, all LV- \& RV-outflow } \\
\text { obstructions, ASD, hypoplastic It heart, ao } \\
\text { stenosis, pulm stenosis, TOF }\end{array}$ \\
\hline Watkins et al & & & 2.0 & $1.2-3.4$ & \\
\hline \multirow[t]{2}{*}{ Cedergen MI, Kallen BA } & Obese & $\begin{array}{l}\text { Overall CHD } \\
\text { Severe } \mathrm{CHD}\end{array}$ & $\begin{array}{l}1.18 \\
1.23\end{array}$ & $\begin{array}{l}1.09-1.27 \\
1.05-1.44\end{array}$ & Only ASD and VSD are significant \\
\hline & Morbidly obese & $\begin{array}{l}\text { Overall CHD } \\
\text { Severe CHD }\end{array}$ & $\begin{array}{l}1.40 \\
1.69\end{array}$ & $\begin{array}{l}1.22-1.64 \\
1.27-2.26\end{array}$ & \\
\hline Watkins ML, Botto LD & \multicolumn{2}{|c|}{ Overweight and obese } & 1.36 & $0.95-1.93$ & $\begin{array}{l}\text { Use of multivitamin did not effect reduction } \\
\text { of anomalies among overweight and obese }\end{array}$ \\
\hline Waller et al & & & 1.26 & $1.11-1.43$ & \\
\hline Leddy et al & & & 1.2 & $1.1-1.3$ & \\
\hline Stothard et al & \multicolumn{2}{|l|}{ Orofacial } & $\begin{array}{l}1.3 \\
\text { OR }\end{array}$ & $\begin{array}{l}1.12-1.51 \\
95 \% \mathrm{Cl}\end{array}$ & $\begin{array}{l}\text { Septal anomaly more common than other } \\
\text { comment }\end{array}$ \\
\hline Moore et al & & & PR 52.2 & $0.91-5.4$ & \\
\hline Rankin et al & $\begin{array}{l}\text { Overall } \\
\text { Cleft lip }\end{array}$ & & $\begin{array}{l}1.76 \\
3.71\end{array}$ & $\begin{array}{l}0.84-3.66 \\
1.05-13.10\end{array}$ & \\
\hline Villamor et al & $\begin{array}{l}\text { Adjusted odds } \mathrm{fc} \\
\mathrm{CP} \text { and all } \mathrm{CP} \text { w } \\
\text { higher for } 3 \mathrm{BMI} \\
\text { between pregna } \\
\text { to } \mathrm{BMI} \text { change } \mathrm{b} \\
<1 \text { units }\end{array}$ & $\begin{array}{l}\text { r both isolated } \\
\text { ere }>2.3 \text { times } \\
\text { units weight-gain } \\
\text { ncies compared } \\
\text { etween }-1 \text { and }\end{array}$ & & & $\begin{array}{l}\text { Increase of } 3 \mathrm{BMI} \text { units } \sim \text { a gain of } 8 \mathrm{~kg} \\
(17.6 \text { pounds })\end{array}$ \\
\hline $\begin{array}{l}\text { Cedergen MI, } \\
\text { Kallen BA }\end{array}$ & $\begin{array}{l}1686 \text { cases @ } 1 \\
\text { CP occurred in } 3 \\
\text { and CLP in } 38 \%\end{array}$ & $\begin{array}{l}.7 / 1000 \text { births. } \\
6 \%, C L \text { in } 25 \% \text {, }\end{array}$ & & & $\begin{array}{l}1408(84 \%) \text { were isolated (i.e. cleft was the } \\
\text { only major malformation) }\end{array}$ \\
\hline Stothard et al & $\begin{array}{l}\text { Septal } \\
\text { Cleft palate } \\
\text { Cleft lip and pala }\end{array}$ & & $\begin{array}{l}1.2 \\
1.23 \\
1.2 \\
\end{array}$ & $\begin{array}{l}1.09-1.31 \\
1.03-1.47 \\
1.03-1.40 \\
\end{array}$ & \\
\hline
\end{tabular}


Maternal Obesity and Congenital Anomalies: Its Implications and Future Trends

Contd...

\begin{tabular}{|c|c|c|c|c|}
\hline \multirow[b]{2}{*}{ Authors } & \multicolumn{4}{|l|}{ Anomalies } \\
\hline & NTD & OR & $95 \% \mathrm{Cl}$ & Comment \\
\hline Moore et al & MSK & PR 1.5 & $0.69-3.4$ & \\
\hline Rankin et al & MSK & 1.77 & $0.16-19.98$ & \\
\hline Waller et al & Limb reduction & 1.16 & $0.89-1.52$ & \\
\hline Stothard et al & Limb reduction & 1.34 & $1.03-1.73$ & \\
\hline Rankin et al & Eye & 11.36 & $2.25-57.28$ & \\
\hline \multirow[t]{2}{*}{ Honein et al } & $\begin{array}{l}\text { Renal anomalies } \\
\text { Obstructive anomalies }\end{array}$ & $\begin{array}{l}5.8 \\
8.5\end{array}$ & $\begin{array}{l}2.0-16.3 \\
2.9-24.7\end{array}$ & \\
\hline & Nonspecific/overall anomalies & OR/PR & $95 \% \mathrm{Cl}$ & Comment \\
\hline Moore et al & $\begin{array}{l}\text { None for BMI > } 28 \text { alone } \\
\text { Combined obesity and Diabetes }\end{array}$ & $\begin{array}{l}\text { PR } 0 . \\
\text { PR } 3.1\end{array}$ & $\begin{array}{c}0.62-1.5 \\
1.2-7.6\end{array}$ & 3 times more risk combined \\
\hline Owens et al & $\begin{array}{l}37(1.6 \%) \text { had congenital } \\
\text { malformations) }\end{array}$ & OR 2.47 & $1.09-5.60$ & $p=0.03$ \\
\hline Shaw et al & $\begin{array}{l}\text { Positive association with overall } \\
\text { NTD }\end{array}$ & & $0.26-0.79$ & $\begin{array}{l}\text { No significant association with other } \\
\text { anomalies. }\end{array}$ \\
\hline Best et al & $\begin{array}{l}\text { Antenatal detection of any } \\
\text { anomaly }\end{array}$ & & & $\begin{array}{l}67(4.0 \%) \text { anomalies occurred in women who } \\
\text { were underweight, } 793(47.0 \%) \text { in women } \\
\text { who were of recommended BMI, } 468(27.8 \%) \\
\text { in women who were overweight and } 358 \\
(21.2 \%) \text { in women who were obese }\end{array}$ \\
\hline Ruager et al & $\begin{array}{l}\text { NTD, CHD, orofacial clefts, } \\
\text { hydrocephalus }\end{array}$ & & & \\
\hline
\end{tabular}

$0.5-1.0$ and 8 per 1,000 births respectively, maternal obesity may result in around 600 NTD and 800 CHD each year. ${ }^{26}$

\section{Contribution to Mortality}

Congenital malformations including chromosomal abnormalities contributed to 5107 (21\%) of total 24,586 infant deaths in the US during 2009 to $2010 .{ }^{27}$ EUROCAT 2007 to 2011 shows a total perinatal mortality due to congenital anomalies to be 0.87 per 1000 births. Congenital anomalies are the second most common cause of infant deaths overall with a rate of 1.39/1000 live births in 2007 and the leading cause of postneonatal death at 0.52/1000 live births. ${ }^{28}$ Approximately, 3\% of pregnancies and infants are diagnosed with congenital anomalies of which $7 \%$ results in stillbirth or infant death. ${ }^{29}$ Since contribution of obesity on congenital anomalies varies from 3\% (for CHD) to $10 \%$ (for NTD), the effect of obesity on infant death and stillbirth could be anywhere between 6 per 1,00,000 (for CHD) to 20 per 1,00,000 (for NTDs).

\section{ECONOMIC IMPLICATIONS}

Although the absolute number of congenital anomalies is not very large, economic and healthcare impact may be substantial due to specialized care needs of many children and adults living with these anomalies. ${ }^{26}$ Estimated medical cost for an infant with any CHD was about 1,00,000 USD in 2005 (for the privately insured) and higher for a major cardiac anomaly. Total hospitalization cost for all individuals with CHD was 1.4 billion USD in $2004 .^{34}$

\section{FUTURE TRENDS}

Birth-defects-prevalence in Europe has decreased from 23.9/10000 to 20.9/10000 between 2003-2007 and 20072011. ${ }^{19,20}$ Birth-defects-mortality has also declined at least in the developed world. It has declined from 255.4/100,000 live births in 1979 to $134.0 / 100,000$ in 2007 in the USA. ${ }^{30}$ On the contrary, obesity in women of childbearing age has been increasing steadily. Health Survey for England (HSE) shows prevalence of obesity among women between 16 and 44 years has increased from about $12 \%$ in 1993 to about $20 \%$ in $2010 .^{31}$ Similar trends are also seen in the US where estimated age adjusted prevalence of obesity in women $>20$ years have increased from $25 \%$ during 1988 to 1994 to about 36\% in 2007 to $2008 .{ }^{32}$ Fisher et al showed a continued upward trend of obesity-prevalence among prepregnant women from 17.6\% in 2003 to $20.5 \%$ in 2009 ( $\mathrm{p}<0.001) .{ }^{33}$ Thus while the prevalence of congenital anomalies and associated infant mortality due to them is declining, obesity (including among women in the childbearing age) is showing a continually upward trend globally. This means that contribution of obesity on congenital anomalies is likely to increase in future particularly as the effects of obesity on maternal and child health become more evident in future.

\section{SUMMARY REMARKS AND CONCLUSION}

- Obesity is increasing globally including among women in the reproductive age group.

- Obesity has been shown to contribute to certain types of congenital malformations particularly NTD, CHD and orofacial defects. 
- Although absolute numbers of congenital anomalies caused by obesity are probably low, healthcare costs are substantial.

- While overall prevalence of congenital anomalies is declining steadily over decades, obesity on the other hand has shown an upward trend. Therefore, contribution of obesity to congenital anomalies may increase in future.

\section{REFERENCES}

1. World Health Organization-Obesity and overweight fact-sheet 311, Updated March 2013 (http://www.who.int/ mediacentre/factsheets/fs311/en/).

2. Heslehurst N, Ells LJ, Simpson H, Batterham A, Wilkinson J, Summerbell CD. Trends in maternal obesity incidence rates, demographic predictors, and health inequalities in 36821 women over a 15-year period. BJOG 2007 Feb;114(2):187-194.

3. Roman H, Goffinet F, Hulsey TF, Newman R, Robillard PY, Hulsey TC. Maternal body mass index at delivery and risk of cesarean due to dystocia in low risk pregnancies. Acta Obstet Gynecol Scand 2008;87(2):163-170.

4. Salihu HM, Lynch O, Alio AP, Liu J. Obesity subtypes and risk of spontaneous versus medically indicated preterm births in singletons and twins. Am J Epidemiol 2008 Jul 1;168(1):13-20.

5. Sahu MT, Agarwal A, Das V, Pandey A. Impact of maternal body mass index on obstetric outcome. J Obstet Gynaecol Res 2007 Oct;33(5):655-659.

6. Leung TY, Leung TN, Sahota DS, Chan OK, Chan LW, Fung TY, Lau TK. Trends in maternal obesity and associated risks of adverse pregnancy outcomes in a population of Chinese women. BJOG 2008 Nov;115(12):1529-1537.

7. Davies GAL, Maxwell C, McLeod L, et al. SOGC Clinical Practice Guidelines: Obesity in Pregnancy. No. 239. 2010 Feb. Int J Gynaecol Obstet 2010 Aug;110(2):167-173.

8. World Health Organization data. Available at: http://apps. who.int/bmi/index.jsp?intro Page=intro_3.html.

9. Moore LL, Singer MR, Bradlee ML, Rothman KJ, Milunsky A. A prospective study of the risk of congenital defects associated with maternal obesity and diabetes mellitus. Epidemiol 2000 Nov;11(6):689-694.

10. Watkins ML, Botto LD. Maternal prepregnancy weight and congenital heart defects in offspring. Epidemiol 2001 Jul;12(4):439-446.

11. Ray JG, Wyatt PR, Vermeulen MJ, Meier C, Cole DE. Greater maternal weight and the ongoing risk of neural tube defects after folic acid flour fortification. Obstet Gynecol 2005 Feb;105(2):261-265.

12. Biggio JR Jr, Chapman V, Neely C, Cliver SP, Rouse DJ. Fetal anomalies in obese women: the contribution of diabetes. Obstet Gynecol 2010 Feb;115(2 Pt 1):290-296.

13. Feldman B, Yaron Y, Critchfield G, Leon J, O'Brien JE, Johnson MP, Evans MI. Distribution of neural tube defects as a function of maternal weight: no apparent correlation. Fetal Diagn Ther 1999 May-Jun;14(3):185-189.

14. World Health Organization — congenital anomalies Fact sheet N³70, October 2012 (http://www.who.int/mediacentre/ factsheets/fs370/en/).

15. Anderson JL, Waller DK, Canfield MA, Shaw GM, Watkins ML, Werler MM. Maternal obesity, gestational diabetes, and central nervous system birth defects. Epidemiology 2005 Jan;16(1):87-92.
16. Hendricks KA, Nuno OM, Suarez L, Larsen R. Effects of hyperinsulinemia and obesity on risk of neural tube defects among Mexican Americans. Epidemiol 2001 Nov; 12(6):630-635.

17. Honein MA, Moore CA, Watkins ML. Subfertility and prepregnancy overweight/obesity: possible interaction between these risk factors in the etiology of congenital renal anomalies. Birth Defects Res A Clin Mol Teratol 2003 Aug;67(8):572-577.

18. Shaw GM, Todoroff K, Schaffer DM, Selvin S. Maternal height and prepregnancy body mass index as risk factors for selected congenital anomalies. Paediatr Perinat Epidemiol 2000 Jul;14(3):234-239.

19. Dolk H, Loane M, Garne E. The prevalence of congenital anomalies in Europe. Adv Exp Med Biol 2010;686:349-364.

20. EUROCAT Prevalence Data Tables: Cases and prevalence (per 10,000 births) of all congenital anomaly subgroups for all registries, from 2007-2011.

21. Boyd PA, Tonks AM, Rankin J, Rounding C, Wellesley D, Draper ES. BINOCAR working group. Monitoring the prenatal detection of structural fetal congenital anomalies in England and Wales: register-based study. J Med Screen 2011;18(1):2-7.

22. BINOCAR (British Isles network of congenital anomaly registers)—Congenital anomaly statistics 2010. July 2012. Available at: http://www.binocar.org/content/Annual\%20 report\% 202010\%20FINAL\%2031_07_12.pdf.

23. National Audit of Treatment for Congenital Heart Disease, NICOR, UCL. Available at: http://fetalanomaly.screening. nhs.uk/fetalanomalyleafletsforprofessionals.

24. Rankin J. Impact of Maternal Obesity on Neural Tube Defects and Cardiovascular Anomalies. 11th EUROCAT European symposium, Antwerp, Belgium, 17th June 2011.

25. Original data source: Office of National statistics. Birth Statistics 2008. Series FM1 no. 37 14th September 2010.

26. Maternal Obesity. Cambridge University Press. Published: August 2012, edited by Matthew W Gillman, Lucilla Poston.

27. National vital statistics reports. Deaths: final data for 2010 by Murphy SL, Xu J, Kochanek KD. Available at: http://www.cdc. gov/nchs/data/nvsr/nvsr61/nvsr61_04.pdf. 2013 May 8;61(4).

28. Office of National Statistics. Mortality Statistics, Childhood, infant and perinatal. Review of the National Statistician on deaths in England and Wales, 2007. Series DH3 number 40. London: Office of the National Statistics 2009.

29. Kurinczuk JJ, Hollowell J, Boyd PA, et al. The contribution of congenital anomalies to infant mortality. National Perinatal Epidemiology Unit, University of Oxford, 2010 June.

30. Birth Defects Prevalence and Mortality. Source: United states environmental protection agency. Available at: cfpub.epa. gov/eroe/index.cfm?fuseaction=detail.viewInd\&lv=list.list byalpha\&r=239796\&subtop $=381$.

31. Prevalence of obesity (with $95 \%$ confidence intervals) in females aged 16-44 years during the period 1993-2010. Available at: www.noo.org.uk/NOO_about_obesity/ maternal_obesity/uk_trends.

32. Ogden CL and Carroll MD. Prevalence of Overweight, Obesity and Extreme Obesity Among Adults: United States Trends 1960-1962 Through 2007-2008. Available at: www. cdc.gov/nchs/data/hestat/obesity_adult_07_08/obesity_ adult_07_08.htm.

33. Fisher SC, Kim SY, Sharma AJ, Rochat R, Morrow B. Is obesity still increasing among pregnant women? Prepregnancy obesity trends in 20 states, 2003-2009. Prev Med. 2013 Jun;56(6):372-378.

34. Centre for disease control and prevention data on congenital heart defects. Available at: http://www.cdc.gov/ncbddd/ heartdefects/data.html. 